\title{
THE DETERMINANT ANALYSIS OF SOCIO ECONOMIC STATUS TO ACCOUNTING LEARNING OUTCOME IN UPI "YPTK" COLLEGE STUDENTS
}

\author{
SUSY YULIASTANTY \\ SIGIT SANJAYA
}

Volume 1 Nomor 1

JIPS ISSN: 2579-5449

\begin{abstract}
ABTRACT
This study aims to analyze (1) the influence of head of household education on accounting learning outcomes, (2) the influence of family head work on accounting learning outcomes, (3) the influence of head of household income on accounting learning outcomes, (4) the influence of family demographics on learning outcomes Accounting (5) the influence of the environment on the learning outcomes of accounting, (6) the influence of internal characteristics of children on the learning outcomes of accounting, (7) the influence of children's gender on accounting learning outcomes, (8) the influence of head of family education, Family demographics, environment, internal characteristics of children and child gender on accounting learning outcomes.

This research type is descriptive associative, where population of this research is all student of UPI "YPTK" majoring in Accountancy, the sample in this research amounted to 247 students taken with multistage

random sampling technique. Hypothesis test using $F$ test and $t$ test with $\alpha=0.05$. The result of the research shows that (1) the education of the head of household has a significant and positive effect on the learning result of accounting (2) the parent's job has a significant and positive effect on the learning result of accounting, (3) the income of the head of family has a significant and positive influence on the learning result of accounting, 4) family demography has significant and negative effect on accounting learning result, (5) environment has significant and negative effect on accounting learning result, (6) internal characteristic of children has significant and positive effect on accounting learning result, (7) child gender has significant effect on result Learning accounting, (8) family head education, family head work, family head's income, family demography, environment, internal characteristics of children and children's gender have a significant effect on accounting learning outcomes.
\end{abstract}

Keywords: accounting learning outcomes, family head education, family head work, family head's income, family demography, environment, internal characteristics, gender

\section{ANALISIS DETERMINAN SOSIAL EKONOMI KELUARGA TERHADAP HASIL BELAJAR AKUNTANSI MAHASISWA UPI "YPTK" PADANG}

\author{
ABSTRAK \\ Penelitian ini bertujuan untuk hasil belajar akuntansi, (3) pengaruh pendapatan \\ menganalisis (1) pengaruh pendidikan kepala kepala keluarga terhadap hasil belajar akuntansi, \\ keluarga terhadap hasil belajar akuntansi, (2) (4) pengaruh demografi keluarga terhadap hasil \\ pengaruh pekerjaan kepala keluarga terhadap belajar akuntansi (5) pengaruh lingkungan
}


terhadap hasil belajar akuntansi, (6) pengaruh karakteristik internal anak terhadap hasil belajar akuntansi, (7) pengaruh gender anak terhadap hasil belajar akuntansi, (8) pengaruh pendidikan kepala keluarga, pekerjaan kepala keluarga, pendapatan kepala keluarga, demografi keluarga, lingkungan, karakteristik internal anak dan gender anak terhadap hasil belajar akuntansi. Jenis penelitian ini deskriptif asosiatif, dimana populasi penelitian ini adalah seluruh mahasiswa UPI "YPTK" jurusan Akuntansi, sampel dalam penelitian ini berjumlah 247 mahasiswa yang diambil dengan teknik multistage random sampling. Uji hipotesis menggunakan uji $\mathrm{F}$ dan uji $\mathrm{t}$ dengan $\alpha=0.05$. Hasil penelitian menunjukkan bahwa, (1) pendidikan kepala keluarga berpengaruh signifikan dan positif terhadap hasil belajar akuntansi (2) pekerjaan orang tua berpengaruh signifikan dan positif terhadap hasil belajar akuntansi, (3) pendapatan kepala keluarga berpengaruh signifikan dan positif terhadap hasil belajar akuntansi, (4) demografi keluarga berpengaruh signifikan dan negatif terhadap hasil belajar akuntansi, (5) lingkungan berpengaruh signifikan dan negatif terhadap hasil belajar akuntansi, (6) karakteristik internal anak berpengaruh signifikan dan positif terhadap hasil belajar akuntansi, (7) gender anak berpengaruh signifikan terhadap hasil belajar akuntansi, (8) pendidikan kepala keluarga, pekerjaan kepala keluarga, pendapatan kepala keluarga, demografi keluarga, lingkungan, karakteristik internal anak dan gender anak berpengaruh signifikan terhadap hasil belajar akuntansi.

Kata kunci: hasil belajar akuntansi, pendidikan kepala keluarga, pekerjaan kepala keluarga, pendapatan kepala keluarga, demografi keluarga, lingkungan, karakteristik internal, gender

\section{PENDAHULUAN}

manusia) menentukan keberhasilan pembangunan, karena itu menjadi penting upaya peningkatan kualitas sumber daya manusia melalui pendidikan dan keterampilan. Konsep pendidikan sebagai sebuah investasi (education as investment) telah berkembang pesat dan diyakini setiap negara bahwa pembangunan di sektor pendidikan merupakan prasyarat kunci bagi pertumbuhan sektor pembangunan lainnya (Irianto,2011:6). Pendidikan juga dipandang sebagai utility, karena di satu sisi pembiayaan dalam pendidikan merupakan kegiatan konsumsi tetapi memberikan nilai guna (utility).Menurut Theodore Schultz, Harvey Leibenstein dan Garry S. Becker dalam Elfindri (2001:42), menganggap bahwa pendidikan sebagai bagian dari investasi yang memberikan keuntungan, baik keuntungan individu, eksternalitas, serta manfaat sosial lainnya.

Pendidikan juga merupakan kegiatan produksi.Dalam ekonomi, proses mengubah masukan menjadi luaran (transforming input to output) di kenal sebagai fungsi produksi (economic production function). Analisis input dan output dalam pendidikan dikenal pula dengan fungsi produksi pendidikan. Untuk memperoleh output pendidikan memerlukan input dan melalui proses. Alexander dan Simmons 1975 dalam Danim (2004:48) melakukan penelitian untuk menganalisis fungsi produksi pendidikan dengan cara membandingkan luaran pendidikan dan masukan.Dalam analisis ekonomi pendidikan, model produksi sedernaha banyak digunakan yang dikenal dengan fungsi produksi pendidikan (educational production function) Hanushek (Palgrave Encyclopedia: 2007).

Luaran (output) dari pendidikan berkaitan dengan mutu dan kualitas manusianya. Dalam mengukur mutu pendidikan dapat dilihat dari performance output pendidikan. Secara umum output pendidikan dapat dilihat melalui beberapa indikator diantaranya secara makro dapat dilihat dari tingkat drop out, rata-rata lama sekolah, angka melanjutkan, angka partisipasi kasar dan secara mikro dapat diukur melalui NEM/IPK dan rata-rata rapor (Elfindri, 2001: 49). Sejalan dengan studi yang dilakukan oleh Koster (2007) menyatakan bahwa output/outcome dari pendidikan adalah hasil pengajaran yang berlangsung di sekolah yang terdiri dari komponen hasil belajar mahasiswa dan konsep diri.Pendekatan yang dilakukan Koster ini merupakan penyederhanaan dari taksonomi pendidikan menurut Bloom bahwa 
pendidikan mencakup kegiatan yang melibatkan ranah pengetahuan kognitif, afeketif dan psikomotornya.

Perbedaan hasil belajar yang dihasilkan oleh masing-masing mahasiswa di UPI "YPTK" disebabkan oleh faktor input yang mendukung dan mempengaruhinya. Sebagaimana dalam fungsi produksi pendidikan yang bermakna mutu dan output dari pendidikan dihasilkan dengan menggunakan sumber (input) tertentu pula (Danim,2004:48). Dalam fungsi produksi pendidikan untuk menghasilkan output pendidikan membutuhkan input seperti karakteristik internal anak, lingkungan keluarga, teman sebaya dan sekolah. Dalam teori fungsi produksi pendidikan Hanushek (1979:355) menyatakan bahwa fungsi produksi pendidikan merupakan analisis umum output dari belajar mahasiswa berhubungan dengan beberapa input diantaranya karakteristik anak, latar belakang keluarga (sosial ekonomi), teman sebaya di sekolah dan karakteristik dari sekolah. Lebih rincinya lagi latar belakang keluarga memiliki karakteristik diantaranya karakteristik sosio demografi keluarga, pendidikan orang tua, pendapatan, dan ukuran keluarga (Hanushek :2007).

Beberapa penelitian terdahulu diantaranya yang dilakukan oleh Orestes (2014:130) menunjukkan bahwa SES (Socioeconomic Status) orang tua berpengaruh signifikan terhadap hasil belajar, Inna Altschul (2012:20) menunjukkan bahwa pekerjaan, pendapatan keluarga dan pendidikan adalah prediktor langsung yang signifikan terhadap hasil belajar, Pamela (2005:297) menemukan bahwa pendidikan dan pendapatan merupakan prediktor yang kuat terhadap hasil belajar, Sirin (2005:438) menemukan bahwa SES keluarga memiliki korelasi yang kuat terhadap prestasi akademik mahasiswa akan tetapi terdapat beberapa penelitian lainnya yang dilakukan oleh Ogunshola (2012:230) menemukan bahwa status sosial ekonomi orang tua dan latar belakang pendidikan orang tua tidak memiliki pengaruh yang signifikan terhadap prestasi akademik mahasiswa dan penelitian yang dilakukan Amarveer Singh; Jai Pal Singh (2014:353) menyatakan bahwa status sosial ekonomi orang tua tidak memainkan peran penting dalam prestasi pendidikan mahasiswa. Oleh karena itu peneliti ingin melihat bagaimana pengaruh SES di kota Padang, apakah SES berpengaruh atau tidak terhadap hasil belajar akuntansi mahasiswa

\section{UPI "YPTK" Padang.}

SES (Social Economic Status) merupakan gagasan yang luas yang mewakili akses keluarga terhadap sumberdaya sosial dan ekonomi (Bradley \& Corwyn, 2002).Konsep status sosial ekonomi mencakup sejumlah variabel, termasuk penghasilan keluarga, tingkat pendidikan orang tua, dan pekerjaan orang tua (Ormrod, 2008:187).Status sosial ekonomi keluarga berpengaruh terhadap prestasi belajar anak (Coleman et al., 1966) dalam Stephen \& Blankston (1997:269).

Status sosial ekonomi sebuah keluarga memberi petunjuk tentang kedudukan keluarga (posisi sosial dan ekonomi) dalam masyarakat. Seberapa fleksibelitas yang dimiliki keluarga dalam hal tempat tinggal dan apa yang mereka beli, seberapa besar pengaruh mereka dalam pengambilan keputusan politis, dan kesempatan pendidikan apa yang dapat mereka tawarkan kepada anak-anak mereka (Ormrod, 2008:187). Sehingga tinggi rendahnya SES keluarga akan mempengaruhi pada pendidikan anak. Menurut J.S. Lee \& Bowen,2006; McLoyd,1998; L.S. Miller, 1995; Sirin,2005 dalam Ormrod (2008:187) siswa dengan SES tinggi cenderung memiliki prestasi akademis lebih tinggi sedangkan siswa SES rendah cenderung memiliki resiko putus sekolah yang lebih besar.

Keluarga dengan status sosial ekonomi tinggi akan lebih sukses dalam mempersiapkan anaknya untuk bersekolah karena mereka memiliki akses yang besar untuk mengembangkan dan mendukung anaknya dari segi mental dan fisik. Keluarga dengan sumberdaya yang memadai akan lebih fokus dalam memenuhi kebutuhan anak baik kebutuhan pokok dan kebutuhan pendidikannya. Pendidikan pertama dan utama bermula dari keluarga. Peran dan latar belakang keluarga sangat besar pengaruhnya dalam pencapaian proses belajar anak untuk memperoleh hasil belajar yang baik.

Pendidikan orang tua merupakan sumberdaya input untuk anak dalam meningkatkan kemampuannya dalam proses belajar. Pendidikan orang tua merupakan penentu yang sangat berpengaruh terhadap pencapaian hasil belajar anak (Haveman, 1993). Baik pendidikan ibu atau pendidikan ayah. Orang tua yang memiliki latar belakang pendidikan yang baik dapat memberikan kemampuan mereka yang berguna untuk peningkatan hasil belajar anak (Lewis: 1973).

Faktor ekonomi juga merupakan 


\section{Jurnal Ilmiah Pendidikan Scholastic}

indikator SES yang penting untuk mendukung output belajar mahasiswa. Anak-anak yang tumbuh dalam kemiskinan akan menderita dengan perkembangan yang terlambat dan ketidakmampuan dalam memperoleh ilmu pengetahuan dibandingkan dengan anak yang berasal dari keluarga yang berpendapatan tinggi (Oretes,2014:127). Sementara itu keluarga dengan pendapatan yang tinggi dapat memenuhi banyak aspek untuk dalam lingkungan keluarga dalam pengembangan pendidikan seperti buku dan beberapa kelengkapan pembelajaran, tempat dan waktu untuk belajar, dan beberapa kebutuhan yang sangat penting (Lewis:1973). Anak membutuhkan ketercukupan kebutuhan baik kebutuhan pokok seperti makan, pakaian dan kesehatan maupun kebutuhan akan kelengkapan fasilitas belajar. Untuk memenuhi kebutuhan dan kelengkapan tersebut diperlukan dana yang memadai. Permasalahan mengenai dana berhubungan dengan pendapatan orang tua.

Determinan sosial ekonomi selanjutnya adalah pekerjaan orang tua. Sebagaimana tinggi rendahnya SES akan mempengaruhi hasil belajar maka pekerjaan orang tua sebagai salah satu dari SES akan mempengaruhi hasil belajar anak. Pekerjaan orang tua dapat dilihat dari jenis pekerjaannya, salah satu jenis pekerjaan adalah bekerja di sektor perdagangan. Dalam proses belajar, anak yang berasal dari keluarga dagang akan lebih terbantu untuk memahami karena mereka dapat langsung menganalisa dan membawakan kepada pekerjaan orang tua mereka, selain itu anak-anak yang berasal dari keluarga yang bekerja di sektor dagang lebih terbiasa dan memahami mengenai kegiatankegiatan ekonomi sehingga dapat membantu mereka dalam proses pembelajaran akuntansi. Selain itu kotaPadang juga merupakan kota dengan sektor unggulan perdagangan.

Faktor lain di luar sosial ekonomi keluarga yang mempengaruhi diantaranya adalah demografi keluarga dengan melihat ukuran keluarga melalui indikator jumlah anak dalam keluarga. Jika jumlah anak dalam keluarga banyak, maka orang tua memiliki sedikit waktu untuk menghabiskan waktu dengan tiap-tiap anak. Sehingga waktu orang tua untuk membimbing dan membantu anak dalam proses belajar akan sedikit. Banyaknya jumlah anak maka suasana rumah akan ramai dan gaduh, sehingga tidak memberikan ketenangan pada anak untuk belajar. Selain itu dengan banyaknya jumlah anak dalam keluarga maka terjadi pelebaran pembelanjaan pendapatan orang tua, dalam artian semakin banyak individu yang menggunakan sumberdaya.

Selain demografi keluarga, kondisi internal anak juga mempengaruhi hasil belajar.Kesehatan jasmani dan rohani sangat besar pengaruhnya terhadap kemampuan belajar. Keadaan jasmani yang segar atau tidak segar, jasmani yang lelah dan yang tidak lelah, serta kesehatan jasmani akan mempengaruhi aktivitas belajar. Hal ini bisa disebabkan oleh kondisi fisik mahasiswa yang dapat dilihat dari massa tubuh mahasiswa, apakah anak memiliki massa tubuh yang ideal atau tidak.

Gender atau jenis kelamin anak juga merupakan faktor yang mempengaruhi hasil belajar anak.Gender menunjukkan pada perilaku atau bentuk aktivitas yang semestinya dilakukan oleh laki-laki dan perempuan. Mahasiswa lakilaki dan mahasiswi perempuan dalam prespektif gender akan memiliki persamaan dan perbedaan secara akademik.

Faktor lain yang mempengaruhi hasil belajar anak adalah lingkungan. Lingkungan merupakan kondisi di luar aspek internal anak.Lingkungan dapat berpengaruh baik dan juga buruk terhadap kegiatan belajar dan hasil belajar anak. Kondisi lingkungan dapat dilihat dari jarak rumah ke sekolah. Jarak antara rumah ke sekolah akan mempengaruhi tingkat kebugaran anak, kelelahan anak, dan biaya yang akan dikeluarkan orang tua untuk anak sehingga akan mempengaruhi tingkat konsentrasi anak dalam belajar dan berdampak pada hasil belajar anak.

Keterkaitan variabel bebas dan terikat dapat digambarkan dalam kerangka konseptual dibawah: 


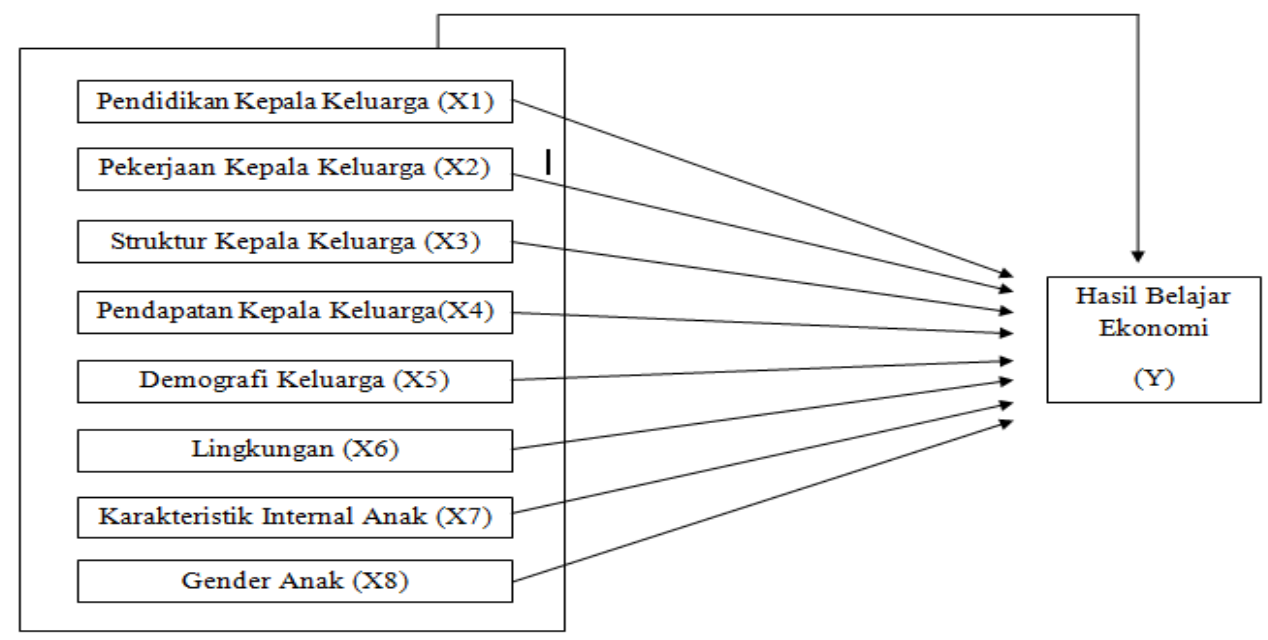

Gambar 1. Kerangka Konseptual

\section{METODE PENELITIAN}

Jenis penelitian ini merupakan penelitian desktiptif asosiatif.Populasi dalam penelitian ini adalah seluruh mahasiswa Jurusan Akuntansi "UPI" YPTK Padang.Pengambilan sampel dalam penelitian ini menggunakan teknik Multistage Random Sampling dengan jumlah sampel sebanyak 247 mahasiswa. Jenis data yang digunakan dalam penelitian ini adalah data cross

\section{PEMBAHASAN HASIL}

Sebelum melakukan analisis regresi berganda, ada beberapa syarat pengujian yang harus dipenuhi agar hasil olahan data dapat menggambarkan apa yang menjadi tujuan penelitian. Pengujian asumsi klasik yang dilakukan adalah Uji Normalitas Residual, Uji Multiko-linearitas, Uji Autokorelasi dan Uji Heteroskedastisitas.

Hasil pengujian normalitas residual menggunakan Kolmogorov-Smirnov terlihat bahwa nilai sig. > 0,05. Ini berarti bahwa data telah memenuhi asumsi distribusi data normal.Kemudian hasil pengujian multikolinearitas menunjukkan bah-wa semua variabel memiliki nilai Tolerance lebih dari 0,10 dan Variance inflation factor (VIF) kurang dari sectiondan sekunder yang diperoleh dari dokumen ujian program studi Akuntansi "UPI" YPTK. Alat analisis yang digunakan dalam penelitian ini yaitu analisis regresi linier berganda. Selain itu, juga dilakukan uji asumsi klasik dan uji kelayakan model yang terdiri dari uji Koefisien Determinasi $\left(\mathrm{R}^{2}\right)$, uji $\mathrm{F}$ statistik, dan yang terakhir uji hipotesis (uji t).

10, sehingga dapat disimpulkan bahwa tidak ada multikolinearitas antar semua varia-bel bebas yang terdapat pada penelitian.Hasil pengujian heterokedastisitas dengan uji Glejser untuk semua variabel independenterlihat bahwa nilai sig. > 0,05, sehingga dapat disimpulkan bahwa varians residual model regresi ini adalah homogen atau model regresi yang diperoleh terbebas dari kasus heterokedastisitas.

Model regresi berganda dalam penelitian ini digunakan untuk menyatakan hubungan fungsional antara variabel bebas dan variabel terikat. Analisis regresi berganda dilakukan dengan menggunakan program Statistical Product and Service Solution (SPSS) 20. Hasil olahan regresi dapat dilihat pada tabel 1 . 
Tabel 1

Coefficients $^{\mathrm{a}}$

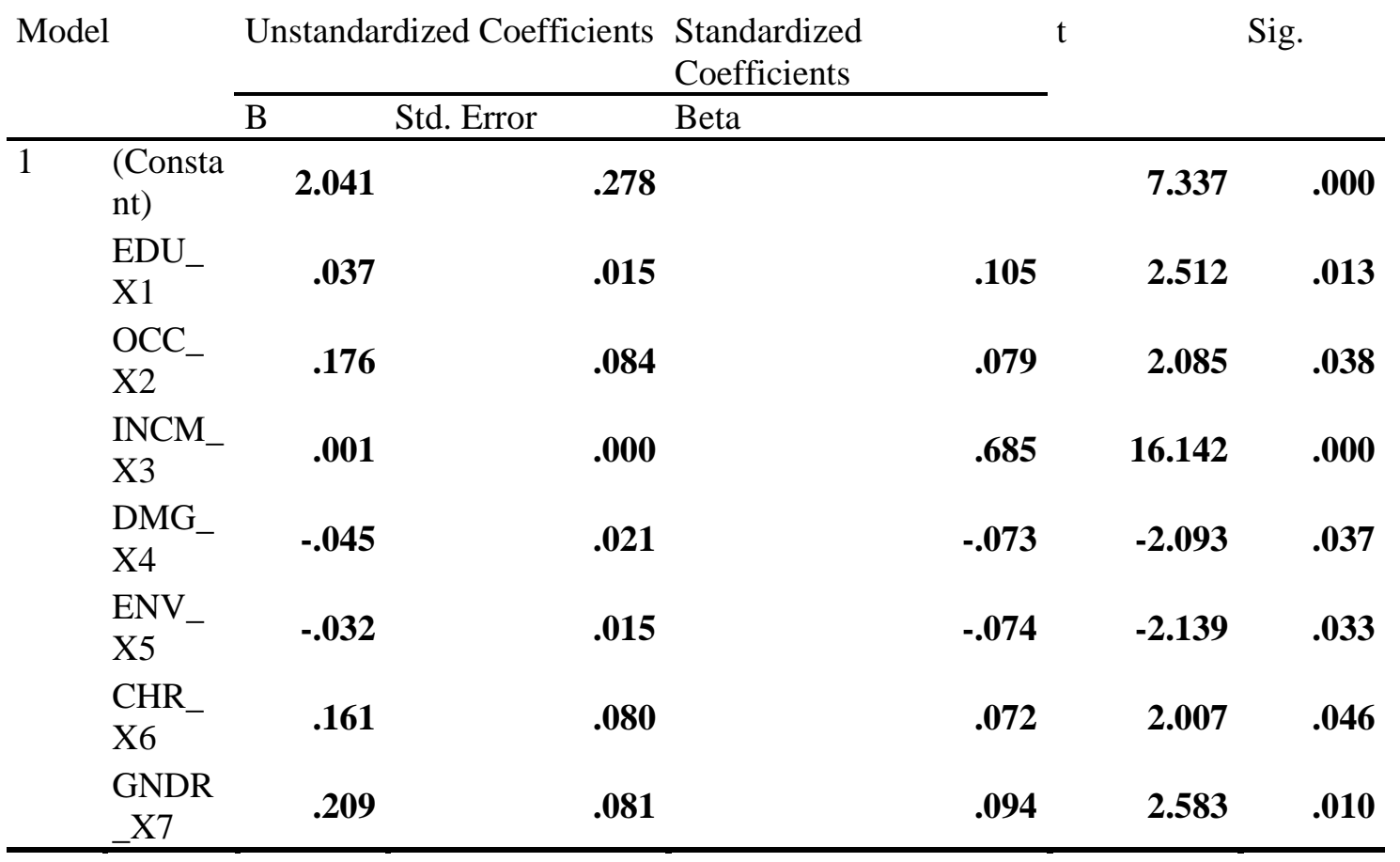

a. Dependent Variable: ACHV_Y

Sumber: Hasil Olahan Statistik SPSS Versi 20

Berdasarkan tabel diatas dapat disajikan analisis sebagai berikut:

$\mathrm{Y}=2.041+0.037 \mathrm{EDU}+0.176 \mathrm{OCC}+$ 0.001INCM + (-0.045) DMG + (-0.032)

ENV + 0.161CHR + 0.209GNDR

Nilai konstanta sebesar 2.041, yang menunjukkan bahwa tanpa adanya pengaruh dari variabel bebas yaitu pendidikan kepala keluarga, pekerjaan kepala keluarga, pendapatan kepala keluarga, demografi keluarga, lingkungan, karakteristik internal anak dan gender mahasiswa maka hasil belajar akuntansimahasiswa sebesar 2.041 .

Koefisien regresi pendidikan kepala keluarga $\mathrm{X}_{1}$ (EDU) sebesar 0.037 menunjukkan bahwa setiap pendidikan ditingkatkan satu satuan, maka hasil belajar mahasiswa akan meningkat sebesar 0.037 satuan dengan asumsi veriabel lain konstan. Koefisien regresi pekerjaan kepala keluarga $\mathrm{X}_{2}$ (OCC) sebesar 0.176 menunjukkan bahwa hasil belajar akuntansi mahasiswa yang perkerjaan kepala keluarganya di sektor dagang/wiraswasta 0.176 lebih tinggi dari hasil belajar akuntansi mahasiswa yang pekerjaan kepala keluarganya di sektor non dagang/wiraswasta. Koefisien regresi pendapatan kepala keluarga $\mathrm{X}_{3}$ (INCM) sebesar 0.001 menunjukkan bahwa setiap pendapatan meningkat satu satuan maka hasil belajar akuntansi mahasiswa akan meningkat sebesar 0.001 satuan dengan asumsi variabel lain konstan. Koefisien regresi demografi keluarga $\mathrm{X}_{4}$ (DMG) sebesar -0.045, menunjukkan bahwa setiap jumlah anak meningkat satu satuan maka hasil belajar akuntansimahasiswa akan menurun sebesar 0.045 satuan dengan asumsi variabel lain konstan. Koefisien regresi kondisi lingkungan $\mathrm{X}_{5}$ (ENVRN) sebesar -0.032 menunjukkan bahwa setiap jarak yang ditempuh mahasiswa meningkat satu satuan maka hasil belajar akuntansimahasiswa akan menurun sebesar 0.032 satuan dengan asumsi variabel lain konstan. Koefisien regresi karakteristik internal anak $\mathrm{X}_{6}$ (CHR) sebesar 0.161 menunjukkan bahwa hasil belajar akuntansi mahasiswa yang memiliki karakteristik internal normal 0.161 lebih tinggi dari hasil belajar akuntansi mahasiswa yang memiliki karakteristik internal yang tidak normal. Koefisien regresi gender anak $\mathrm{X}_{7}$ (GNDR) sebesar 0.209 menunjukkan bahwa hasil belajar akuntansi mahasiswi perempuan 0.209 lebih tinggi dari hasil belajar akuntansi mahasiswa laki-laki 
Hasil pengukuran koefisiean determinasi dapat dilihat pada tabel 2 berikut:

Tabel 2

Adjusted R Square

Model Summary

Model R R Square Adjusted R Std. Error of

\begin{tabular}{lllll} 
& \multicolumn{2}{c}{ Square } & \multicolumn{2}{c}{ the Estimate } \\
\hline 1 & $\mathbf{. 8 5 0}^{\mathbf{a}}$ & $\mathbf{. 7 2 2}$ & $\mathbf{. 7 1 4}$ & $\mathbf{. 5 9 1 0 0}$ \\
\hline a. Predictors: (Constant), GNDR & X7, DMG X4, ENV X5,
\end{tabular}

a. Predictors: (Constant), GNDR_X7, DMG_X4, ENV_X5,

OCC_X2, CHR_X6, EDU_X1, INCM_X3

Sumber: Pengolahan data statistic SPSS Versi.20

\begin{abstract}
Nilai $\mathrm{R}$ Square $\left(\mathrm{R}^{2}\right)$ atau koefisien determinasi adalah 0.722 , hal ini mengindikasikan bahwa kontribusi variabel pendidikan kepala keluarga, pekerjaan kepala keluarga, pendapatan kepala keluarga, demografi keluarga, lingkungan, karakteristik internal anak dan gender adalah sebesar $72,2 \%$ terhadap hasil belajar akuntansi (Y), sedangkan 27,8\% lainnya
\end{abstract}

ditentukan oleh faktor lain diluar model yang tidak diteliti dalam penelitian ini.

Hasil uji $F$ yang dilakukan untuk mengetahui apakah semua variabel bebas secara bersama-sama memiliki pengaruh yang signifikan terhadap variabel terikat hasil belajar akuntansi dapat dijelaskan melalui tabel 3 dibawah.

Tabel 3

\begin{tabular}{|c|c|c|c|c|c|c|}
\hline \multirow[b]{2}{*}{ Model } & \multicolumn{6}{|c|}{$\begin{array}{c}\text { Tabel 3 } \\
\text { Uji F } \\
\text { ANOVA }\end{array}$} \\
\hline & & $\begin{array}{l}\text { Sum of } \\
\text { Squares }\end{array}$ & $\mathrm{Df}$ & $\begin{array}{l}\text { Mean } \\
\text { Square }\end{array}$ & $F$ & g. \\
\hline 1 & $\begin{array}{l}\text { Regressio } \\
n\end{array}$ & 216.634 & 7 & 30.948 & 88.604 & $.000^{b}$ \\
\hline & Residual & 83.478 & 239 & .349 & & \\
\hline & Total & 300.113 & 246 & & & \\
\hline
\end{tabular}

a. Dependent Variable: ACHV_Y

b. Predictors: (Constant), GNDR_X7, DMG_X4, ENV_X5, OCC_X2, CHR_X6, EDU_X1, INCM_X3

Berdasarkan hasil dari olahan data pada tabel 3 diperoleh level signifikansi sebesar 0.000 . Jika dibandingkan dengan nilai signifikansi yang ditentukan pada penelitian ini sebesar 0.05 , maka level signifikansi hasil pengolahan data lebih kecil dari level signifikansi yang ditentukan yang akibatnya $\mathrm{H}_{0}$ ditolak dan $\mathrm{H}_{\mathrm{a}}$ diterima. Terbukti bahwa pendidikan kepala keluarga $\left(\mathrm{X}_{1}\right)$, pekerjaan kepala keluarga $\left(\mathrm{X}_{2}\right)$, pendapatan kepala keluarga $\left(\mathrm{X}_{3}\right)$, demografi keluarga $\left(\mathrm{X}_{4}\right)$, kondisi lingkungan $\left(\mathrm{X}_{5}\right)$, karakteristik internal anak $\left(\mathrm{X}_{6}\right)$ dan gender anak $\left(\mathrm{X}_{7}\right)$ secara bersamasama berpengaruh signifikan terhadap hasil belajar Akuntansi (Y).

Uji $t$ dilakukan untuk mencari pengaruh variabel bebas terhadap variabel terikat dalam persamaan regresi secara parsial dengan mengasumsikan variabel lain dianggap konstan. Uji $t$ dilakukan dengan membandingkan antara nilai $t$ hitung dengan nilai $t$ tabel.Hasil pengolahan pada tabel 1 , untuk hipotesis pertama $t_{\text {hitung }}$ yang diperoleh sebesar 2.512 jika dibandingkan dengan $t_{\text {tabel }}=1.9699$, maka dapat diketahui bahwa $\mathrm{t}_{\text {hitung }} 2.512>\mathrm{t}_{\text {tabel }} 1.9699$ atau Sig $0.013<0.05$. Dengan demikian dapat disimpulkan bahwa terdapat pengaruh signifikan positif antara pendidikan kepala keluarga $\left(\mathrm{X}_{1}\right)$ terhadap hasil belajar Akuntansi (Y).

Hipotesis kedua, $t_{\text {hitung }}$ yang diperoleh sebesar 2.085 jika dibandingkan dengan $\mathrm{t}_{\text {tabel }}=$ 1.9699, maka dapat diketahui bahwa $\mathrm{t}_{\text {hitung }} 2.085$ $>\mathrm{t}_{\text {tabel }}$ 1.9699atau Sig $0.038<0.05$. Dengan 
demikian dapat disimpulkan bahwa terdapat pengaruh yang positif dan signifikan antara pekerjaan kepala keluarga $\left(\mathrm{X}_{2}\right)$ terhadap hasil belajar akuntansi (Y).

Hipotesis ketiga, $\mathrm{t}_{\text {hitung }}$ yang diperoleh sebesar 16.142 jika dibandingkan dengan $t_{\text {tabel }}$ $=1.9699$, maka dapat diketahui bahwa $\mathrm{t}_{\text {hitung }}$ $16.142>\mathrm{t}_{\text {tabel }} 1.9699$ atau Sig $0.000<0.05$ dengan demikian dapat disimpulkan bahwa terdapat pengaruh yang positif dan signifikan antara pendapatan kepala keluarga $\left(X_{3}\right)$ terhadap hasil belajar akuntansi (Y).

Hipotesis keempat, $\mathrm{t}_{\text {hitung }}$ yang diperoleh sebesar -2.093 jika dibandingkan dengan $\mathrm{t}_{\text {tabel }}=$ 1.9699, maka dapat diketahui bahwa $t_{\text {hitung }}-2.093$ $>\mathrm{t}_{\text {tabel }} 1.9699$ atau Sig $0.037<0.05$. Dengan demikian dapat disimpulkan bahwa terdapat pengaruh yang negatif dan signifikan antara demografi keluarga $\left(\mathrm{X}_{4}\right)$ terhadap hasil belajar akuntansi (Y).

Hipotesis kelima, $\mathrm{t}_{\text {hitung }}$ yang diperoleh sebesar -2.139 jika dibandingkan dengan $t_{\text {tabel }}=$

\section{PEMBAHASAN}

Hasil perhitungan secara simultan (Uji F) menunjukkan bahwa variabel pendidikan kepala keluarga $\left(\mathrm{X}_{1}\right)$, pekerjaan kepala keluarga $\left(\mathrm{X}_{2}\right)$, pendapatan kepala keluarga $\left(\mathrm{X}_{3}\right)$, demografi keluarga $\left(\mathrm{X}_{4}\right)$, kondisi lingkungan $\left(\mathrm{X}_{5}\right)$, karakteristik internal anak $\left(\mathrm{X}_{6}\right)$ dan gender anak $\left(\mathrm{X}_{7}\right)$ secara bersama-sama berpengaruh signifikan terhadap hasil belajar akuntansi $(\mathrm{Y})$.

\section{Pengaruh Pendapatan Kepala Keluarga Terhadap Hasil Belajar Akuntansi Mahasiswa Akuntansi UPI "YPTK"}

Berdasarkan hasil penelitian pada tabel 1 dapat diketahui bahwa pendapatan kepala keluarga merupakan variabel yang sangat besar pengaruhnya.Pendapatan kepala keluarga berpengaruh signifikan terhadap hasil belajar akuntansi.Bentuk pengaruh variabel pendapatan orang tua terhadap hasil belajar mahasiswa yang dilihat dari pendapatan kepala keluarga adalah positif.Hal ini berarti bahwa semakin tinggi tingkat pendapatan kepala keluarga maka cenderung semakin tinggi pula hasil belajar mahasiswa.

Hasil penelitian ini sejalan dengan pendapat J.S. Lee \&
1.9699, maka dapat diketahui bahwa $\mathrm{t}_{\text {hitung }}-2.139$ $>\mathrm{t}_{\text {tabel }} 1.9699$ atau Sig $0.033<0.05$ dengan demikian dapat disimpulkan bahwa terdapat pengaruh yang negatif dan signifikan antara lingkungan $\left(\mathrm{X}_{5}\right)$ terhadap hasil belajar akuntansi (Y).

Hipotesis keenam, $t_{\text {hitung }}$ yang diperoleh sebesar 2.007 jika dibandingkan dengan $\mathrm{t}_{\text {tabel }}=$ 1.9699, maka dapat diketahui bahwa $t_{\text {hitung }} 2.007$ $>\mathrm{t}_{\text {tabel }} 1.9699$ atau Sig $0.046<0.05$. Dengan demikian dapat disimpulkan bahwa terdapat pengaruh yang positif dan signifikan antara karakteristik internal anak $\left(\mathrm{X}_{6}\right)$ terhadap hasil belajar akuntansi (Y).

Hipotesis ketujuh, $t_{\text {hitung }}$ yang diperoleh sebesar 2.583 jika dibandingkan dengan $\mathrm{t}_{\text {tabel }}=$ 1.9699, maka dapat diketahui bahwa $t_{\text {hitung }} 2.583$ $>\mathrm{t}_{\text {tabel }} 1.9699$ atau Sig $0.010<0.05$. Dengan demikian dapat disimpulkan bahwa terdapat pengaruh yang positif dan signifikan antara stuktur keluarga $\left(\mathrm{X}_{7}\right)$ terhadap hasil belajar akuntansi (Y).

Bowen,2006; McLoyd,1998; L.S. Miller, 1995; Sirin,2005 dalam Ormrod (2008:187) siswa dengan SES tinggi cenderung memiliki prestasi akademis lebih tinggi. Sejalan dengan pendapat diatas Slameto (2010:63) mengemukakan bahwa keadaan ekonomi keluarga erat hubungannya dengan hasil belajar mahasiswa.Anak yang sedang belajar selain harus terpenuhi kebutuhan pokoknya misal makanan, pakaian, perlindungan kesehatan dan lain-lain, juga membutuhkan fasilitas belajar seperti ruang belajar, meja, kursi, penerangan, alat-alat tulis, buku-buku dan lain-lain. Pemenuhan fasilitas belajar akan dapat terpenuhi jika keluarga memiliki cukup uang. Dan didukung oleh Dalyono (2007:59) bahwa besar kecilnya penghasilan keluarga mempengaruhi pencapaian hasil belajar mahasiswa

\section{Pengaruh Gender Anak Terhadap Hasil Belajar Akuntansi Mahasiswa Akuntansi UPI "YPTK"}

Berdasarkan hasil penelitianda tabel 1 diketahui terdapat pengaruh yang 
signifikan antara variabel gender mahasiswa terhadap hasil belajar akuntansi Mahasiswa UPI "YPTK". Bentuk pengaruh variabel gender anak adalah positif. Hal ini berarti bahwa gender perempuan memiliki hubungan yang positif terhadap hasil belajar akuntansi.

Hal ini sesuai dengan penelitian yang dilakukan oleh Halpem(2006) dalam Surna \& Pandeirot (2014) yang menemukan bahwa pada sekolah SMA di Amerika menunjukkan bahwa hasil belajar siswi perempuan lebih lebih tinggi dibandingkan laki-laki. Hal ini disebabkan perempuan lebih bisa berkonsentrasi dalam belajar, menyediakan waktu untuk belajar serta berupaya berpartisipasi aktif dalam kelas dan usaha lainnya yang bertujuan untuk memperoleh hasil belajar yang optimal.

Hasil penelitian ini konsisten dengan hasil penelitian yang dilakuakan oleh Pamela (2005) bahwa gender memiliki pengaruh terhadap hasil belajar. Selain itu hasil penelitian ini juga sama dengan hasil penelitian Engine \& Demir (2009) bahwa gender memiliki pengaruh terhadap hasil belajar anak miskin perkotaan Turki.

\section{Pengaruh Pendidikan Kepala Keluarga Terhadap Hasil Belajar Akuntansi Mahasiswa Akuntansi UPI "YPTK"}

Berdasarkan analisis data pada tabel 1 diketahui bahwa terdapat pengaruh yang signifikan antara tingkat pendidikan kepala keluarga terhadap hasil belajar akuntansi Mahasiswa Akuntansi "YPTK".Bentuk pengaruh variabel pendidikan kepala keluarga terhadap hasil belajar akuntansi Mahasiswa Akuntansi "YPTK" adalah positif. Temuan ini menunjukkan bahwa semakin tinggi pendidikan kepala keluarga maka akan cenderung semakin tinggi hasil belajar akuntansi anak.

Hasil penelitian ini sesuai dengan pendapat Oretes (2014:130) bahwa pendidikan orang tua berpengaruh terhadap hasil belajar anak di sekolah.Sejalan dengan hasil penelitian diatas penelitian yang dilakukan Inna
(2012) menemukan bahwa pendidikan ayah dan pendidikan ibu berpengaruh besar terhadap hasil belajar anak di Meksiko. Dengan latar belakang pendidikan yang tinggi maka orang tua akan mempunyai gambaran yang lebih jelas terhadap masa depan anaknya, hal ini akan menuntun orang tua untuk memberikan bimbingan dan arahan dalam proses pendidikan anaknya.

\section{Pengaruh Lingkungan Terhadap Hasil BelajarAkuntansi Mahasiswa Akuntansi UPI "YPTK"}

Hasil penelitian pada tabel 1 menunjukkan bahwa variabel lingkungan berpengaruh signifikan terhadap hasil belajar akuntansi mahasiswa "UPI" YPTK.Bentuk pengaruh variabel lingkungan terhadap hasil belajar akuntansi adalah negatif.Hal ini berarti semakin dekat jarak dari rumah menuju sekolah maka hasil belajar akuntansi anak menjadi lebih baik.

Hasil penelitian ini sejalan dengan pendapat Syah (2012:154) bahwa lingkungan non sosial turut menentukan tingkat keberhasilan belajar siswa diantaranya adalah sekolah dan letaknya, tempat tinggal dan letaknya, alat belajar, cuaca, dan waktu.

Kondisi lingkungan yang dilihat dari jarak tempuh rumah ke kampusakan mempengaruhi kondisi fisik anak. Jarak rumah ke kampus yang jauh mempengaruhi kondisi jasmani anak yang dapat menyebabkan kelelahan, turunnya semangat belajar dan fokus anak dalam belajar.Sehingga dapat disimpulkan jarak dari rumah ke kampus memiliki pengaruh terhadap hasil belajar mahasiswa.

\section{Pengaruh Demografi Keluarga Terhadap Hasil Belajar Akuntansi Mahasiswa Akuntansi "YPTK"}

Berdasarkan hasil penelitian pada tabel 1 diketahui terdapat pengaruh yang signifikan antara variabel demografi keluarga terhadap hasil belajar akuntansi mahassiwa UPI "YPTK".Bentuk pengaruh variabel demografi keluarga terhadap hasil belajar akuntansi adalah negatif. Hal Ini menunjukkan bahwa 
semakin banyak jumlah anak dalam keluarga maka cenderung hasil belajar akuntansi mahasiswaakan menurun.

Hasil penelitian ini sejalan dengan pendapat Slameto (2010:63) suasana rumah yang gaduh/ ramai dan semrawut dapat terjadi pada keluarga yang terlalu besar yang tidak akan memberikan ketenangan kepada anak dalam belajar.

Demografi keluarga yang dilihat dari jumlah anak mempengaruhi hasil belajar. Jika keluarga berukuran besar maka pendistribusian pendapatan kepada anak akan melebar, sehingga untuk memenuhi kebutuhan materil anak dalam proses belajar menjadi kurang optimal. Selain itu keluarga yang berukuran besar, masing-masing anak akan mendapatkan perhatian yang kurang maksimal dari orang tua terlebih lagi perhatian dalam pengawasan, dan proses belajar anak. Demografi keluarga memiliki pengaruh terhadap hasil belajar akuntansi, implikasinya adalah baik sekolah maupun pemerintah dalam memberikan layanan pendidikan perlu memperhatikan demografi keluarga. Baik dalam proses belajar dan memberikan bantuan pendidikan bagi mahasiswa, demografi keluarga perlu diperhatikan.

\section{Pengaruh Pekerjaan Kepala Keluarga Terhadap Hasil Belajar Akuntansi Mahasiswa Akuntansi "YPTK"}

Hasil penelitian pada tabel 1 menunjukkan bahwa variabel pekerjaan kepala keluarga berpengaruh signifikan terhadap hasil belajar akuntansi mahasiswa UPI "YPTK".Bentuk pengaruh variabel pekerjaan kepala keluarga terhadap hasil belajar akuntansi adalah positif.

Pekerjaan orang tua merupakan salah satu variabel konsep status sosial ekonomi (SES).Menurut Coleman dalam Stephen dan Blankston (1997) status sosial ekonomi keluarga berpengaruh terhadap hasil belajar.Hal ini berarti bahwa pekerjaan orang tua mempengaruhi hasil belajar.Hasil penelitian ini sejalan dengan hasil penelitian yang dilakukan oleh Orestes
(2012) bahwa terdapat pengaruh yang signifikan antara pekerjaan orang tua dengan hasil belajar anak di Tanzania.

Pekerjaan kepala keluarga dalam penelitian ini diklasifikasikan menjadi bekerja di sektor dagang dan wiraswasta dan bekerja di sektor non dagang dan wiraswasta.Berdasarkan analisis deskriptif data sekitar $57.89 \%$ orang tua mahasiswa bekerja di sektor dagang/ wiraswasta.Hal ini berarti kebanyakan dari mahasiswa memiliki orang tua yang bekerja di sektor perdagangan dan wiraswasta.Anak-anak yang orang tuanya bekerja di sektor dagang dan wiraswasta maka mereka dekat dengan aktifitas yang berhubungan dengan kegiatan ekonomi. Sehingga mereka akan terbantu dalam memahami pelajaran akuntansi.

Pekerjaan kepala keluarga memiliki pengaruh terhadap hasil belajar akuntansi, implikasinya adalah sekolah perlu lebih meningkatkan perhatian kepada anak-anak yang berasal dari keluarga yang bekerja di bidang selain dagang dan wiraswasta untuk membantu mereka lebih mengerti dan memahami aplikasi dari mata pelajaran akuntansi dalam kehidupan nyata.

7. Pengaruh Karakteristik Internal Anak Terhadap Hasil Belajar Akuntansi Mahasiswa Akuntansi UPI "YPTK"

Berdasarkan hasil analisis pada tabel 1 diketahui terdapat pengaruh yang signifikan antara karakteristik internal anak terhadap hasil belajar akuntansi mahasiswa UPI "YPTK".Bentuk pengaruh variabel karakteristik internal anak terhadap hasil belajar akuntansi adalah positif. Hal ini berarti bahwa semakin normal kondisi fisik anak maka hasil belajar akan semakin meningkat.

Hasil penelitian ini sejalan dengan pendapat Syah (2012:130) bahwa kondisi jasmani yang menandai kebugaran organ tubuh dan sendi dapat mempengaruhi semangat dan intensitas siswa dalam mengikuti pelajaran. Hal ini akan berpengaruh terhadap hasil belajar anak. Sejalan dengan pendapat diatas menurut Dalyono (2007:55) bahwa kesehatan jasmani dan rohani sangat 


\section{Jurnal Ilmiah Pendidikan Scholastic}

besar pengaruhnya terhadap kemampuan belajar. Selanjutnya menurut Slameto (2010:54) kesehatan seseorang berpengaruh terhadap belajarnya karena proses belajar seseorang akan terganggu jika kesehatan seseorang terganggu.

Hasil penelitian ini sejalan dengan hasil penelitian yang dilakukan Engine \& Demir (2009), bahwa karakteristik internal anak berpengaruh signifiakan terhadap hasil belajar anak sekolah dasar di Turki. Kesehatan tubuh anak akan mempengaruhi kemampuan anak dalam menyerap informasi dan pengetahuan. Kondisi fisik yang tidak bugar dan lesu akan menganggu proses belajar yang akan mempengaruhi hasil belajar. Anak yang memiliki kondisi fisik yang normal cenderung akan lebih bagus hasil belajar akuntansinya dibandingkan anak yang memiliki kondisi fisik tidak normal. Anak yang tidak normal kondisi fisiknya (kurus, gemuk, obesitas) lebih memiliki resiko kesehatan yang akan mengganggu ketahanan fisik sehingga berdampak pada konsentrasi dan proses belajarnya.

Karakteristik internal anak berpengaruh terhadap hasil belajar akuntansi, implikasinya adalah bagi orang tua harus lebih memperhatikan asupan gizi, waktu tidur, istirahat anak.selain itu orang tua juga harus mampu mengingatkan anak untuk berolahraga, rekreasi dan ibadah secara teratur. Sedangkan untuk pihak sekolah dengan mengetahui masing-masing karakteristik internal anak maka sekolah akan mampu menganalisa kemungkinankemungkinan yang akan terjadi pada anak-anak yang memiliki kondisi internal yang tidak normal dan mampu memberikan kualitas proses pembelajaran yang lebih baik.

\section{KESIMPULAN}

Hasil analisis dari penelitian ini menunjukkan bahwa tingkat pendidikan kepala keluarga berpengaruh positif dan signifikan terhadap hasil belajar akuntansi mahasiswa UPI "YPTK".Variabel pekerjaan kepala keluarga berpengaruh positif dan signifikan terhadap hasil belajar akuntansi mahasiswa UPI "YPTK".Variabel pendapatan kepala keluarga berpengaruh signifikan dan positif terhadap hasil belajar akuntansi mahasiswa UPI "YPTK" Variabel demografi keluarga berpengaruh signifikan dan negatif terhadap hasil belajar akuntansi mahasiswa UPI "YPTK".Variabel lingkungan berpengaruh negatif dan signifikan terhadap hasil belajarakuntansi mahasiswa UPI "YPTK".Variabel karakteritik internal anak berpengaruh positif dan signifikan terhadap hasil belajar akuntansi mahasiswa UPI "YPTK".Variabel gender berpengaruh signifikan terhadap hasil belajar akuntansi mahasiswa UPI "YPTK". Hal ini menunjukkan bahwa mahasiswi perempuan memiliki hubungan yang positif terhadap hasil belajar akuntansinya dibandingkan anak laki-laki.

Pendidikan kepala keluarga, pekerjaan kepala keluarga, pendapatan kepala keluarga, demografi keluarga, lingkungan, karanterinstik internal anak, dan gender anak bersama-sama mempengaruhi hasil belajar akuntansi mahasiswa UPI "YPTK" dengan tingkat sumbangan kedelapan variabel adalah sebesar $72.2 \%$ dan $27.8 \%$ dipengaruhi oleh faktor-faktor lain yang tidak dibahas dalam penelitian ini.

Dari simpulan dalam penelitian ini, maka disarankan Kepada tenaga pengajar, masyarakat dan pemerintah diharapkan dapat membantu mahasiswa dan mahasiswi yang berasal dari keluarga yang memiliki pendapatan rendah sehingga mereka dapat kuliah dan belajar dengan baik tanpa terbebani dengan kondisi finansial keluarga yang lemah.Diharapkan orang tua serta tenaga pengajar memperhatikan dan membantu mahasiswa dalam proses belajar dengan juga memperhatikan gender, dan karakteristik internal mahasiswa. Anak laki-laki memerlukan perhatian dan bimbingan yang lebih baik lagi, dan anakanak yang memiliki karakteristik internal yang tidak normal perlu mendapatkan asupan gizi yang lebih baik, olahraga yang rutin, serta dapat menjadi pertimbangan bagi guru dalam membantu proses belajar.

Disamping itu pihak sekolah tinggi maupun pemerintah dalam memberikan layanan pendidikan perlu memperhatikan demografi keluarga. Baik dalam proses belajar dan memberikan bantuan pendidikan bagi 
mahasiswa, demografi keluarga perlu diperhatikan.Peran yang besar dari tenaga pengajar sangat menentukan keberhasilan mahasiswa dalam belajar.Mahasiswa yang berasal dari orang tua yang berpendidikan rendah perlu mendapatkan perhatian dan bimbingan yang lebih oleh tenaga pengajar dalam meningkatkan hasil belajarnya karena orang tua mereka memiliki keterbatasan dalam membantu anaknya jika mengalami kendala dalam belajar. Penelitian ini masih terbatas pada ruang lingkup yang kecil dan diharapkan pada peneliti selanjutnya untuk meneliti faktor-faktor lain yang mempengaruhi hasil belajar mahasiswa, dan demi kesempurnaan penelitian ini, penulis berharap ada yang mengadakan penelitian lebih lanjut dengan alat uji yang lebih baik.

\section{DAFTAR PUSTAKA}

Arikunto, Suharsimi. 2006. Prosedur Penelitian Suatu Pendekatan Praktik. Jakarta: Rineka Cipta

Becker, Gary. 1960. An Economic Analysis of Fertility.Columbia University and National Bureau of economic Research

Bogges, Scott. 1998. Family Structure, Economic Status, and Educational Attainment. Journal of Population Economics, Vol. 11, No. 2

Dalyono. 2007. Psikologi Pendidikan. Jakarta: Rineka Cipta

Danim, Sudarwan. 2004. Ekonomi Sumber Daya Manusia.Jakarta: Pustaka Setia

Elfindri.2001. Ekonomi Sumber Daya Manusia, Universitas Andalas, Padang

Engin \& Demir. 2009. Factors influencing the academic achievement of the Turkish urban poor. International Journal of Educational Development 29 (2009) 1729

Gary N. Marks. 2006. Family Size, Family Type and Student Achievement: CrossNational Differences and the Role ofSocioeconomic and School factors. Journal of Comparative Family Studies, Vol. 37, No. 1

Hanushek, A Eric. 1979. Conceptual and Empirical Issues in the Estimation of Educational Production Function. The Journal of Human Resources, Volume 14, Issue 3.354:363
Hanushek, A Eric. 2007. Education Production Function. Palgrave Encyclopedia

Idris. 2008. Aplikasi Model Analisis Data Kuantitatif Dengan Program SPSS. Padang: FE UNP

Inna Altschul.2012. Linking Socioeconomic Status to the Academic Achievement of Mexican American Youth Through Parent Involvement in Education. Journal of the Society for Social Work and Research, Vol. 3, No. 1

Irianto, Agus. 2011. Pendidikan sebagai Investasi dalam Pembangunan suatu Bangsa. Jakarta: Kencana

Irianto, Agus. 2010. Statistika Konsep, Dasar, Aplikasi, dan Pengembangannya. Jakarta: Kencana Prenada Media Group

Isjoni. 2006. Pendidikan Sebagai Investasi Masa Depan. Jakarta: Yayasan Obor Indonesia

Kathryn S. Schiller, Vladimir T. Khmelkov and Xiao-Qing Wang.2002.Economic Development and the Effects of Family Characteristics on Mathematics Achievement. Journal of Marriage and Family,Vol. 64, No. 3

Koster, Wayan. 2007. Pengaruh Input Sekolah Terhadap Outcome Sekolah Survai di SLTP Negeri DKI Jakarta. http://www.depdiknas.go.id/publikasi/bal itbang/025/j25-04.pdf

Lewis, J Perl.1973.Family Background, Secondary School expenditure, and 
Student Ability. The Journal of Human Resources Vol 8, No 2: 160.

Mankiw, Gregory. 2006. Principles of economics "Pengantar Ekonomi Mikro".Salemba Empat

Marlaine E. Lockheed, Bruce Fuller and Ronald Nyirongo. 1989. Family Effects on Students' Achievement in Thailand and Malawi. Sociology of Education,Vol. 62, No. 4

Megan De Serf. 2002. The Effects of Family, Social and Background Factors on Children's Educational Attainment. Research Honors Project, Department of Economics

Orestes, Silverius Kapinga. 2014. The Impact of Parental Socioeconomic Status on Students' Academic Achievement in Secondary Schools in Tanzania. International Journal of Education Vol. 6, No. 4

Ormrod, Ellis Jeanne.2008. Psikologi Pendidikan. Jakarta: Erlangga

Pamela, E Davis Kean. 2005. The Influence of Parent Education and Family Income on Child Achievement: The Indirect Role of Parental Expectations and the Home Environment. Journal of Family Psychology 2005, Vol. 19, No. 2, 294304

Priyatno, Duwi. 2012. Cara Kilat Analisis Data dengan SPSS 20. Edisi Kesatu. Yogyakarta: ANDI

Simanjuntak, Payaman J.1998. Ekonomi Sumber Daya Manusia.Jakarta: FE UI

Slameto.2010. Belajar Dan Faktor-Faktor Yang Mempengaruhinya. Jakarta: Rineka
Cipta

Slavin, E Robert.2011. Psikologi Pendidikan: Teori dan Praktik. Jakarta: PT Indeks

Sudjana, Nana.2011. Penilaian Hasil Proses Belajar Mengajar. Bandung: PT Remaja Rosdakarya

Sugiyono. 2006. Metode Penelitian Kuantitatif. Bandung: Alfabeta

Sukirno, Sadono. 2000. Pengantar Teori Mikroekonomi.Jakarta: Raja Grafindo Persada

Surna \&Pandeirot.2014.Psikologi Pendidikan 1. Jakarta: Erlangga

Supardi.2005. Metode Penelitiaan Ekonomi dan Bisnis. Yogyakarta: UII Press

Suryabrata, Sumadi. 2012. Psikologi Pendidikan. Jakarta: Rajawali Pers

Syah, Muhhibin. 2012. Psikologi Belajar. Jakarta: Rajawali Pers

Todaro, Michael dan Stephan C. Smith, 2009.Pembangunan Ekonomi Edisi kesembilan. Jakarta:Erlangga

Udida, Lucy Ambeken, Ukwayi, Joseph. K, Ogodo, Francis Agwanyang. 2012. Parental Socioeconomic Background as a Determinant of Student's Academic Performance in Selected Public Secondary School in Calabar Municipal Government Area, Cross River State, Nigeria. Journal of Education and Practice Vol 3, No 16

Winkel, W.S. 1996. Psikologi Pengajaran. Jakarta: Grasindo 